problem in that it does not communicate to the layman. It does not

Solution?

There is indeed a solution to the problem. trarily selecting one of the definitions and stipulating that this shall henceforth be THE definition. Nor is altempting a composite definition which covers eu
tingency especially helpful.

Rather the solution must be centered in an honest attempt by all of us to communicate arl times to all our audiences. It is our respon all times to all our audiences. It is our respon-
sibility to stipulate clearly the definition under which we are currently operating. Further, and simultaneous to the above, we must continually monitor the field outside of our own personal domain to keep For a final word we turn to J. Gass, the director of the Center for Educational Re search and Innovation, from a report pub Educational technology: The design and im.
plementation of learning systems. His comment at once shows the complimentary and integrative possibility between the physical the same time, projects the possibilities for the future:

The simple lesson. . . is that there is no tech nological miracle in education. Neither the television camera, nor the computer, nor education. . . Educational technology is not a bag of mechanical tricks, but the organized design and implementation of learning sys. miracles from mocer, bu not expecting methods, visual aids, classroom organization and teaching methods.

References

Association for Educational Communication tion and Terminologk. The en Definin educational technology, Washington,

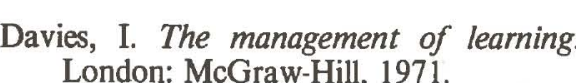

Educational technology: The design and im plementation of learning systems,
C.E.R.I., Organization for Economic Co-operation and Development, 1971.

Haney, J.B. \& Ullmer, E.J. Educational me Wm. C. Brown Co., 1970.

Haney, J.B. \& Ullmer, E.J. Educationa communications and technology: An in troduction for teachers. Dubuque,
Iowa: Wm. C. Brown Co., 1975 . Rowntree, D. Educational technology in curriculum development. London: aettler, P. A history of instructional tech-
nology. New York: McGraw Hill, 1968.

Salomon, G. "What is learned and how it Message, task and learner." In 0 .
David R. (Ed.) Media and symbots forms of expression, communication and education, 73rd Yearbook of the
National Society for the Study Education, 1974 .

Skinner, B.F. The technology of teachine New6

Wittich, W.A. \& Schuller, C.W. Audiowis York: Harper and Row, 1962

Wittich, W.A. \& Schuller, C.W. Instructio al technology: Its nature and use. (Sixth
ed.) New York: Harper \& Row, 1979

\section{CLOSE HARMONY}

A $30 \mathrm{~min}$. colour film which will win the hearts of everyone who

The students captured in the opening frames of CLOSE "God would like us to be joyful!" These fourth and fifth graders 1979-1980 class of Friends School in Brooklyn, New York, have ample reason to be happy. They are members of an "intergenerational "chorus comprised of "youngsters" from nine to ninety, and their story is truly an inspiring one. Arlene Symons, originator and director of the group, first conceived teacher and as a group worker in senior citizens' centers She brought the two disparate groups together in concert and parent Nigel Noble recorded the entire process on film. A CINE Golden Eagle Winner.

Available for preview for purchase consideration.

M MARLIN Motion Pictures Ltd. MARLIN Motion Pictures Lto

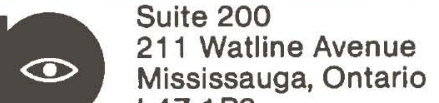
666 St. James Street

L4Z 1 P3
$(416) 272-4100$ Winnipeg, Manitoba R3G $3 J 6$
(204) $774-0632$

\section{Memorial University's ETV Centre Goes Public}

Duane B. Starcher 
enrollment peaks passed through the university about five years ago, so such an undetaking as MUN-TV has to be justified on cultural grounds rather than in response to
clear-cut, concrete instructional problems apparent to the general public, as were the
educational pressures in the 1960 's.

Specific Restrictions

What did we know before we started? We realized that we could never afford even to consider an open broadcast mode of signal never provide a television home in the city if the university had to bear the capital costs of the delivery system. We would have been forever restricted to disributing credit courses via videotape to botres; we would thus be bound to produce programs primarily in aid of the prescribed, formal purposes of institutions. They would be eacher-loaded, not student-centered or "in in our province.

"We realized that we could never afford even to consider an open broadcast mode of signa delivery.

\section{A Cable Channel}

Even in our most optimistic deliberations,

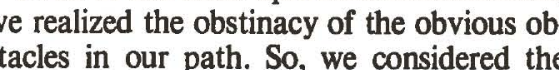
problem and re-defined those limitations as virtues. Our vehicle into the home was through Avalon Cablevision Limited, the United States signals imported by microwave from Maine via Nova Scotia. We requested a channel for the university, independent of the company's legal obligation to provide a nel was cheerfully granted as a condition of their license.
Cable and Telephone Playback to pay $\$ 25.00$ for a cable hook-up and $\$ 9.51$ per month would not have at least one telements, cable from the universily to the homes and viewers' telephones reaching out, we introduced PLAYBACK, a ser vice through which anyone could call us and lection. We began with less titles from which to choose, but have built that now to over 1,000 . Between November 1978 and April, 1981, we responded to

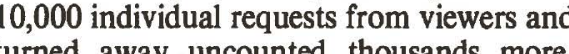
PLAYBACK was fully booked nearly every working

\section{Building the Collection}

So, instead of taking the traditional approach to public broadcasting, we concersources of free films, low cost film any re vision programs, spiced with a few "biggies," expensive leaders to attract notice among the "competition," the commerical channels. No matter what titles eventually ended up in ou tive service and retained only 12 hours in prime time out of each 60-hour week which we programmed, in the traditional mold of and professionalism high. And we concenttrated our own production effort to creat local programming intended to supply a basic core of intelligent productions bot about the university and about topics on which expertise
some light.

Looking Back

In retrospect, these strategies were not
merely successful, they proved to be our salmerely successful, they proved to be our salvation. We had assessed our weaknesses an useful to our viewers in that we were seen to be providing a service; we were responsible in that we could react to viewers' needs; $w$ were crealing a resource, a collection more form of television in our viewers' experie And, we were avoiding near certain failure by not attempting to mimic traditional operations for which we were not equipped, always undertaking production tasks tha tained an operation of which we could proud and which was seen to be of profof sional standard,

“...we introduced PLA BACK, a service through whi anyone could call us and ask the replay of any program in collection."

\section{Reaching Out \\ Only new money could take us beyond also consider watching ou
time programs at night.} John's out where our presence was even
more important than in the city. Obviously we were always concentrating on the "ted" service province-wide. We had spent the la two years trying to find the physical and nancial means to delivery our signal
stream, that is, from east to west. This week's programming and live coverage d major oil conference province-wide, but the money to support a fulltime network has to viously not yet come through. Our intent was someday to serve, by microwave,
lowns of Gander, Grand Fall, Deer IA tephenville, Corner Brook and Port Basques, all of which have commercial cul systems in place. These particular tow he Terra Nova Tel microwave route, the tariff charges inhibit our establishmet on the network. The distribution technolu is available, waiting for us to activat cable services, but are off the main min wave spine. These, and all sites in Labrad would have to be served later, probaty satellite.
Problems and Solutions
As I began by reporting the demise of the ke now to talk about some of the problem foperating such a service and discuss some the solutions we were coming to term with.

LAYBACK Met Needs

PLAYBACK had the tremendous advanhours of programs from a rather small collection of titles. To have scheduled 10,000 programs in two and a half years in the tradj-
tional manner would have bankrupted us tional manner would have bankrupted us
even sooner. Through PLAYBACK, we were offering a service to individuals; and we
were becoming known to viewers who would were becoming known to viewers who would
also consider watching our scheduled, prime-

We faced exactly the opposite roblem of a commercial entrepreneur - we didn't dare be too popular...

Popular Titles y popularity of some of our titles. There cast programs such as "Cars that Crash and urn," (108 times) "Small Cars and Crashes" 156 times) and "Crashes that Need Not Kill" but the kids requested them mostly for the ow-motion sequences of death and destruccome a bit embarassing, some that I proFolklore Deself. They were done with our loundland Country Music Pioneers." "The lipe seen to be in operation by those who
lipped in

What was beginning to distress us was the times and the one on Wilf Doyle 94 times Wif Dis was before Conception Harbour, cable! It began to seem as if everytime we
looked at our channel it either had a car crash or a hillbilly on it - not really your vice. Limiting Programs

We early took the steps of limiting any while. Then we bought "All You Need is Love" from TVOntario, thirteen hours of pop music, so theoretically we could have 26 hours of such music each week. We sthe other titles caused a bit of trouble. everal programs from Wayne State disassed the evolution of the horror film. Th pos not particularly disturbing until a paren showed children killing their parents - and then eating them. This, and a few other titles of a sensitive nature were restricted to play-
ing after 9:00 p.m., that is, well after supper.

..we concentrated our own production effort to create local programming. .

Free Films

As we had collected many titles from sources of free films, we also on occasion had about the companies that sponsored the films. On the other hand, most free programs did contain much good information and $\mathrm{ex}$ cellent visual material. Beggars could not at-
ways be choosers, nor did we want to be come censoring gatekeepers any more tha Changes

So, what changes would we have made if PLAYBACK had not been suspended? can't say for sure, but a number of idea opening a second channel in the mideand (soon to be activated by Avalon Cablevision) new MUN-TV itself for a better controlled better balanced form of access television. We also the titles that had been played to death, but as new subscribers were constantly being the reason that they were popular. We faced exactly the opposite problem of a commercial entrepreneur - we didn't dare be too popular, especially when display the image the university wished to portray before the public.

Another option, and one with much merit, money in catoses a deal of money in catalogues and postage, was
changing the requestable titles each week restricting PLAYBACK to fifteen or twenty titles, but not limiting the number of plays of
any of those titles. Notices could have been run on our information display system, as well as printed in the newspapers and TV guides sold in the city. In other words, we
could have incorporated the information
about PLAYBACK into normal procedures for listing scheduled programs.
As we have no idea when or if PLAY.
BACK can be restored, we don't have to face these decisions yet. Perhaps you will have
other ideas to suggest that will be of use other ideas to suggest that will be of use
when the time comes to reintroduce the service.

This, then, is what we have been doing beyears. The public channel has been a spur to us all in the range and quality of our produc foundland some of you bun binto Newfoundland some of your own best produc
tions. We combined scheduled and access modes and laid the groundwork for our inevitable extension to the other cities with cable services. We were well on our way.

tion is now less clear. Our 1981-82 season will be exciting, but not reactive. We will schedule our own programs and promote better times next year. 